\title{
Dark Manners
}

\section{Sue Kneebone}

\begin{abstract}
This essay examines the research intent and material processes behind my exhibition project Dark Manners (2013). The exhibition examined the belief systems of nineteenth-century scientists and the notion of Australia as a nebulous laboratory at the far edges of empire. In doing so, it interrogated the dark issues of colonial settler identity that continue to strain at the moral integrity of Australian national identity. In broader terms, I look at how the transformative process of the craft of bricolage may help to raise, expand and reshape critical awareness of historically inscribed notions of identity in relation to place, while also communicating other perspectives and critical viewpoints.
\end{abstract}

This hall, in which he was now left alone, was a pet fancy of his friend the doctor's; and Utterson himself was wont to speak of it as the pleasantest room in London. But to-night there was a shudder in his blood; the face of Hyde sat heavy on his memory; he felt (what was rare with him) a nausea and distaste of life; and in the gloom of his spirits, he seemed to read a menace in the flickering of the firelight on the polished cabinets and the uneasy starting of the shadow on the roof. He was ashamed of his relief, when Poole presently returned to announce that Dr. Jekyll was gone out.

(The Strange Case of Dr Jekyll and Mr Hyde, Stevenson 1886: 27)

The house of Dr Jekyll and Mr Hyde stands as a metaphoric representation through place of the conflicted identity of its inhabitants. To the street, it is the handsome home of the upstanding Dr Jekyll, who entertains his friends in 'the pleasantest room in London'; to the rear, it is the laboratory where lurks Dr Jekyll's alter ego, the evil Mr Hyde. Robert Louis Stevenson's classic Gothic tale The Strange Case of Dr Jekyll and Mr Hyde symbolises a duplicity in which comfort and respectability is unsettled by a dark menace and hidden crimes.

As a place where conflict of identity resides, Dr Jekyll's house opens a door to our own unsettled place in the world. Exploring notions of Australian colonial settler identity as being out of place at the far edges of empire is a recurrent theme in my work as a visual artist. This field of inquiry raises the issue of a non-Indigenous relationship to the land as being an uncanny mix of uncertainty, anxiety, arrogance and strangeness - an unsettling malaise that filters through to the present. In this essay, I consider Australia's sense of place and identity in colonial settler society through an investigation of nineteenth-century scientific practices in Australia and Britain, as represented in the exhibition Dark Manners. 
In Dark Manners, held at the Contemporary Art Centre of South Australia (CACSA) in Adelaide in 2013, I explored the medical frontier from a time when a growing interest in the natural sciences and evolutionary theory led to a dark and complex trade between colonial Australia and the centre of empire. It delved into the murky morality of respectable men of medicine in nineteenthcentury Australia and Britain, who procured and donated human and animal remains for museum collections. Dark Manners looked at the notion of Australia as a nebulous laboratory at the far edges of empire where gentlemen scientists were the shadowy subjects of their own curious predilection for collecting. In the exhibition, I employed material hybridity as a way to craft an uneasy tension between the unspoken interiority of polite society and the duplicity of dark deeds committed in the interests of humankind, which continue to haunt the present.

The intention behind this exhibition project was to understand and represent the ethics and belief systems in British scientific thinking at the time of Australia's colonisation, and how those systems remain hidden in the present. One of the key areas of interest was researching the British experimental surgeon and comparative anatomist John Hunter who, as surgeon extraordinary to King George III, was a significant figure in Georgian high society. Hunter's quest for new medical discoveries reflected scientific thinking from the age of enlightenment, an era that preceded and overlapped the British settlement of Australia in the late eighteenth century. His work, and in particular the home where he worked, are said to have inspired a vital element of Stevenson's Gothic tale of Dr Jekyll and Mr Hyde.

\section{Settler society and the Australian Gothic}

In my studio research, I seek ways to recast the past in its complexity by invoking the strangeness of colonial settlers inhabiting a strange land. For my doctoral research project, 'Naturally Disturbed' (Kneebone 2010), I implicated my own colonial settler-farming family as I gained a deeper understanding of the impact that nineteenth-century society has on the present through the social and environmental effects of introduced land-use practices.

Investigations from a postcolonial perspective of the Gothic genre of literary fiction have helped me to encapsulate and frame my material responses to the darkness of this colonial past. Gothic fiction was popular throughout the time of British settlement in Australia in the eighteenth and nineteenth centuries. A number of theorists have explored the origins of Australian Gothic including, in the Anthology of Colonial Australian Adventure Fiction, Ken Gelder and Rachel Weaver, who point out that adventure stories and the colonial agenda are closely bound up with one another, although the relationship is a troubled one shadowed by darkness (2011: 1-2). Gerry Turcotte proposes that the 
Gothic mode is ideal for conveying a sense of spiritual malaise that is specific to the Australian colonial experience because of its associations with fear, uncertainty, isolation and the unknown (2005). The anxieties experienced at isolated stations, being at the mercy of nature, frontier conflict and becoming lost in the bush are examples that he explores as unique to the Australian Gothic experience. Turcotte explains how the Gothic mode, as a hybrid form, works by fragmentation, borrowings and conflations. In doing so, it lends itself to surreal and uncanny fabrications where the unfamiliar is imposed on the familiar.

Research suggests that the genre of colonial adventure fiction was popular because it resonated with the colonial experience and helped to frame Australia's fledgling sense of identity (Foster et al. 2001: 99).

In her book Fantastic Metamorphosis, Other Worlds, Marina Warner postulates that the Gothic sensibility was a literary tool for 'turning on its head the governing notion of Otherness' (2002: 24). She intimates that tales of metamorphosis often occur at points of interchange or cross-cultural zones. Warner explains how such transformations allow the rules of natural order to be broken, and invite us to enter an imaginative realm where reverie may help us to think otherwise (2002: 18). This corresponds to the Australian colonial experience in which cross-cultural encounters in an unfamiliar place lend themselves to the Gothic sensibility as a popular form of expression.

Pierre Nora's metaphorical description of revived memories existing in transient states ties in with the notion of the Gothic being materially suspended in an unresolved state, neither dead nor alive (1984, cited in Farr 2012: 61-66). This fits with Eve Sedgewick's reading of the Gothic trope of the 'live burial' as a metaphor for a 'repressed thing that threatens to return' (cited in Halberstam 1995: 72). Judith Halberstam explains how the power of Gothic as a narrative technique 'can spin the sentimental into something abhorrent, and then frames this transformation within a humanist moral fable' (1995: 73). Drawing on these analyses of the Gothic in relation to my artworks, I suggest the transformation of images and objects into materially unresolved states is a way to draw attention to the spectre of concealed histories with dark moral undertones that threaten to return and haunt us in uncanny ways.

Cultural theorist Jane Goodall notes how ideas of the colonial and postcolonial uncanny have been circulating since around the turn of the millennium, with varying lines of interpretation. She explains how, in the Australian context, responses come from a postcolonial condition as a 'state of ambivalence and contradiction in which "a certain unboundedness" is making itself evident in the settler relationship to the land' (2013).

The dark undercurrents and Gothic descriptions conveyed in much Australian colonial literature has helped to inform and rouse a darker side to my artwork. 


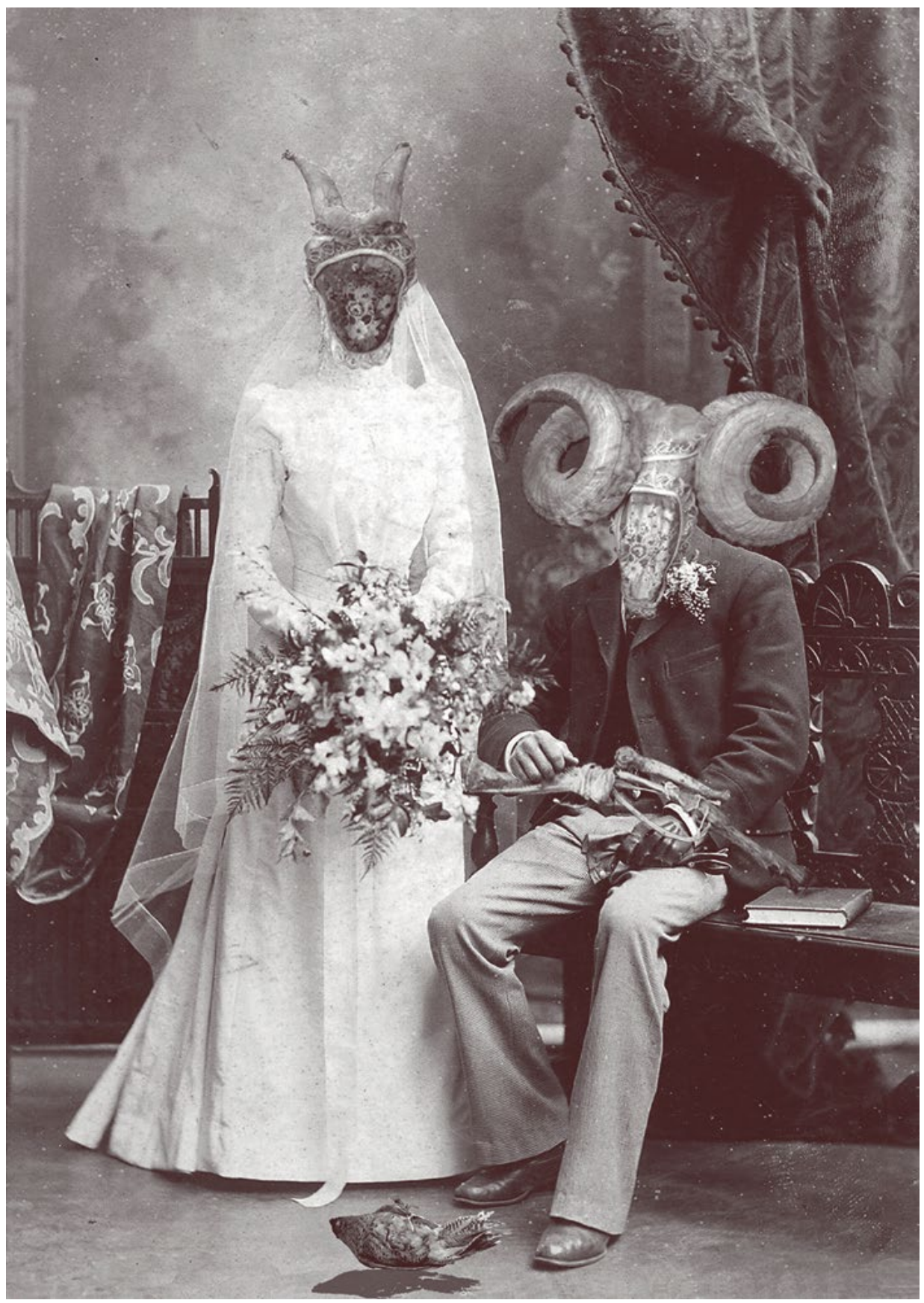

Figure 1. Sue Kneebone, For better or for worse, 2010, archival print, $73 \times 95 \mathrm{~cm}$ Photo: Sue Kneebone 
I used the process of photomontage, which helps to produce disparities and contradictions that interrupt continuity of experience, to invoke this Gothic sensibility in my studio practice. Different images placed together combine as a new form or concept arising from the juxtaposition. The work For better or for worse (2010), for example, was an outcome of this process. This transmogrified wedding portrait from the late 1890s of my great-grandparents becomes a foreboding tale of impending environmental catastrophe. Before them lies the night parrot, a vulnerable ground dweller from the Gawler Ranges, which is now believed to be extinct as a result of habitat destruction and the introduction of feral animals such as cats and foxes. Through the process of montage I have implicated my grazier ancestors in this difficult past.

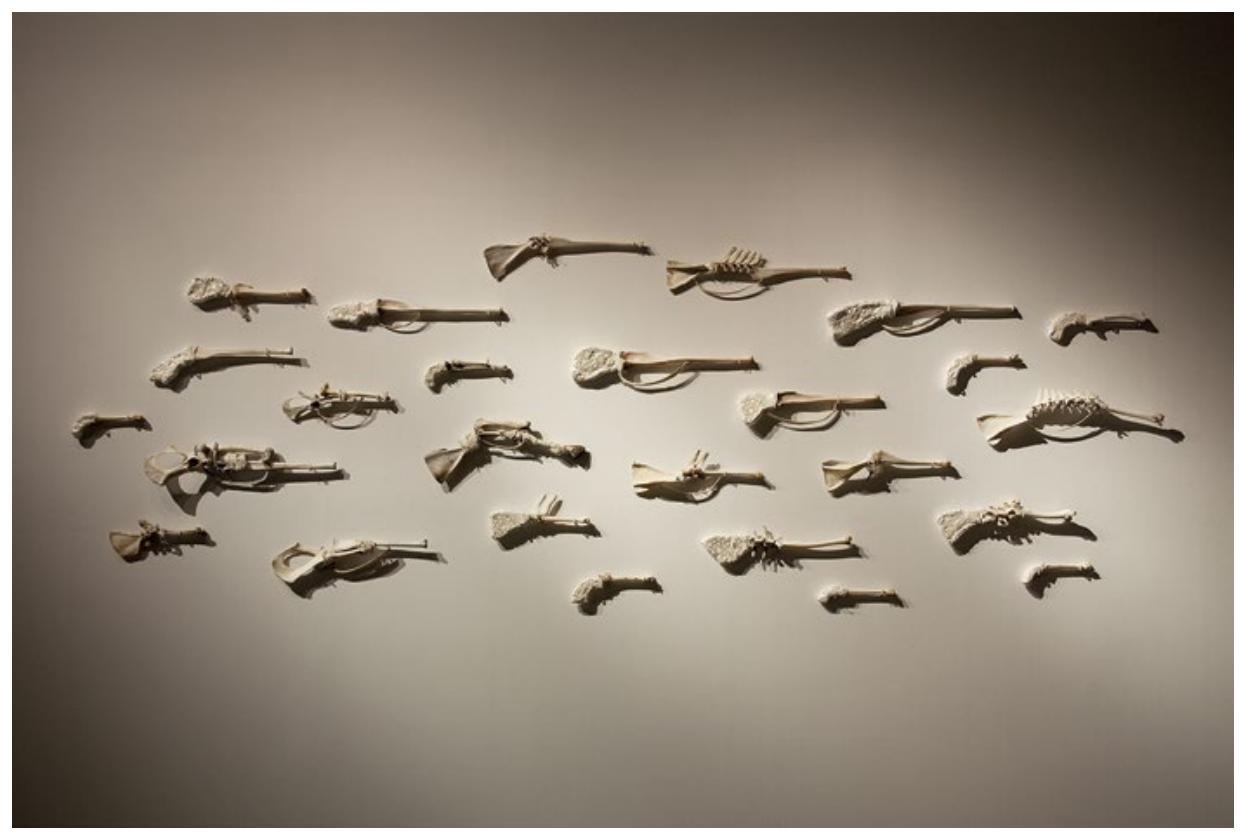

Figure 2. Sue Kneebone, Angelfire, 2008, bones and mixed media, approx. $200 \times 200 \mathrm{~cm}$

Photo: Chris Boha

The craft of bricolage is the structural process of bringing together disparate objects to form a work of art. Art theorist Johnathon Katz notes how the epistemological and multivalent nature of assemblage has the capacity to communicate different lines of meaning to different audiences (2008: 45). The inherent instability of bricolage, with its juxtaposition of incongruous materials, may lead to assembled forms that challenge the narratives and conventions of history. In my work, bricolage helps to establish narrative connections between memory and archival fragments of history. For example, Angelfire (2008) is an installation of guns crafted from animal bones found in the Gawler Ranges pastoral region of South Australia, where my great-grandparents ran a sheep 
property. Guns played a dark part in frontier conflict and in opening up the landscape for pastoral use, while also erasing native ecologies. Corresponding to the Gothic trope of the 'live burial', bones have been resurfaced and transformed into metaphorical guns to invoke unsettled memories from the colonial past.

By using the transformative processes of photomontage and bricolage, the art forms that I create seek to traverse time, memory and place to convey loss, myths and silences from the disturbed and unsettled past of colonial settler society. My intention is to lead the viewer to consider the more insidious subtexts behind these images arising from the legacy of colonial incursions.

\section{Hunter's House and the Hunterian Museum}

John Hunter (1728-93), surgeon to George III and an esteemed man of medicine in eighteenth-century British society, ran an anatomy school at the back of his house on Leicester Square in London. The exhibition plan of Dark Manners was loosely informed by a sketch of the rooms in Hunter's house, which is believed to have later inspired the setting for Stevenson's 1886 Gothic novella The Strange Case of Dr Jekyll and Mr Hyde (Moore 2005: 430). The ingenious layout of Hunter's home was designed to separate the two worlds of good and evil. At the front of Hunter's house was the parlour room, where patients were received in the morning and society guests in the evening. A marble staircase led to a first-floor salon where guests 'recited, danced and gossiped until the early hours' (Moore 2005: 433). Meanwhile, a corridor downstairs led to the rear of the house where a four-storey structure housed the anatomy school, which included a grand reception room, lecture theatre and museum. Hidden furthest from the general household was an attic that housed Hunter's dissecting room. The back of the house opened out to a busy thoroughfare at 13 Castle Street where, at night, body-snatchers, known as 'resurrection men', would surreptitiously deliver corpses across a lowered drawbridge, which could be swiftly raised to prevent entry. This unique layout allowed Hunter to range freely between the cultural entertainment of Georgian society, taking place in the salon room overlooking the gardens of Leicester Square, and another world of death and dissection at the rear (Moore 2005: 432-33).

Like the house of Dr Jekyll and Mr Hyde, Hunter's house would come to 'symbolize the mutually dependent but conflicting aspects of Hunter himself, at once the esteemed society surgeon pursuing a laudable quest for medical advancement and the obsessive collector immersed in illicit activities in order to enlarge his hoard of human and animal parts at whatever cost' (Moore 2005: 432). 
Hunter was well connected and his friends included the naturalist Sir Joseph Banks, who was also an adviser to George III. Banks urged the monarch's support in the discovery of new lands including the Endeavour's expedition under James Cook to find 'The Great South Land'. On his return from this expedition in 1771, Banks gave Hunter the skull of a kangaroo-it was intended to be a complete specimen but the carcass was eaten by the ship's crew, hungry for fresh meat (Moore 2005 : 284-322). As only the skin and bone of the kangaroo remained, the first English attempt to paint one, by George Stubbs in 1772, could only be an approximate forensic interpretation. From this time on, Australia became a kind of curious ecological laboratory in the interests of colonial expansion.

Although Hunter held unorthodox views that questioned the biblical age of the earth and documented variations within species, he passed away some 70 years before Charles Darwin's The Origin of Species was published in 1859, which created a new demand in the minds of naturalists for the comparative study of animal and human specimens (Moore 2005: 495). A dark trade between the centre of empire and its colonies began in earnest.

Even long after his death, Hunter's name was connected with the amassing of human and animal collections at the highest level of the British scientific community. The Royal College of Surgeons' Hunterian Museum in London, named in Hunter's honour, holds an extensive collection of anatomical specimens. It and the Anatomical Museum of Edinburgh University were among a number of nineteenth-century British anatomy collections that I visited in 2012 during a research trip to the United Kingdom. Fieldwork, which has been an integral part of my studio research, enriches the experiential side of research that is unobtainable from archival sources. The images and installations in Dark Manners were in part informed by visiting these institutions. Jane Goodall recalls how, in her own visits to these museums, she was 'disconcerted by the mismatch of form and texture: the geometry of the display cases with their polished wood and glass, against the matted fur and porous bone of the objects inside' (2013).

In the Hunterian Museum's archive of correspondence, a table of listings that gives precedence to the name of the collector over the nature of human remains highlights the pragmatics of scientific collecting. The examples below list some of the human remains that travelled from Australia to Britain from the 1860s, in particular exchanges involving Sir William Henry Flower, conservator of the Hunterian Museum from 1862 to 1884, and then director of the Natural History Museum in London from 1884 to 1898. The correspondence shows that Flower was receiving animal and human remains from across Australia and the globe while he was in these positions. 
craft + design enquiry

1864, Sir William Flower, to William Lodewyk Crowther, Australian and Tasmanian animal skeletons.

1871, Morton Allport (sender), to unknown recipient, Skeletons of two Tasmanian Aboriginals.

1870, Robert Henry Armit, naval surveyor to Sir William Henry Flower, knight, zoologist-Skull and artifacts from Australia.

1898, James A. Bonnin, to unknown recipient. Skeleton of South Australian.

1871, H. Girdlestone. To Sir William Henry Flower. Offering 2 Native Australian Bears and one Celus-La-Gontus for sale.

\section{Adelaide collectors}

In 1896, around the time of Sir William Flower's retirement, Scottish physician, naturalist and anthropologist William Ramsay Smith arrived in Adelaide to take up a pathology position at the Royal Adelaide Hospital. Ramsay Smith simultaneously held positions as the city coroner, chairman of the Central Board of Health and the anatomy inspector, which allowed him to collect human remains by dubious means (Macdonald 2010).

Adelaide has been identified in regard to human remains as the 'most fruitful source of material due to the anthropological interests of several leading figures within its medical school, established in 1885' (Turnbull 2012: 12). Edward Charles Stirling (1848-1919), during his tenure as professor of physiology at the University of Adelaide from 1885 and as director of the South Australian Museum from 1884 to 1912, actively encouraged the acquisition of Aboriginal skulls and skeletons, 'to study what he believed were evolutionarily significant features of the Aboriginal body' (Turnbull 2012: 12). Both Stirling and Ramsay Smith were part of a systematic trade of human material with leading British anatomists, such as William Turner, who was professor of anatomy at Edinburgh University from 1863 to 1916.

Ramsay Smith was responsible for the bulk of Edinburgh University's physical anthropology collection, which held the remains of some 500 to 600 individuals, many of which were collected surreptitiously and by dubious means from burial sites, including Ngarrindjeri burial grounds in the sand dunes of the Coorong (Scobie 2009). At the time of Ramsay Smith's death in 1937, an astounding 182 skulls were found in his Adelaide home. Mike Pickering, Repatriation Program director at the National Museum of Australia, suggests that 'Ramsay Smith was body shopping-collecting individuals of unusual pathologies or disease. He was trying to buy favour and kudos with his alma mater' (Scobie, 2009). 


\section{Dark Manners - The exhibition}

By drawing on the plan of Hunter's house for the exhibition layout of Dark Manners, I established a metaphor of duplicity for darker aspects of Australian colonial settler society. The exhibition venue, Contemporary Art Centre of South Australia (CACSA), is a late nineteenth-century house located in the quiet, well-heeled inner suburb of Parkside on the southern fringes of the Adelaide Parklands. Nearby, the historic Parkside asylum was an occasional source of the bodies that were procured by anatomists for museums and collectors. Thus, the locale and history of Parkside and the gallery added to the auratic feel and intention of the exhibition to invoke the past.

CACSA has three main exhibition spaces under one roof, which neatly allowed me to replicate aspects of Hunter's house layout, with the front room representing the salon or parlour room, the central room a museum or lecture room, and the back room being the space hidden away for receiving bodies and preparing dissections.

With its period-style furniture, the front gallery room became a sinister veneer to hide the memory of colonial settler society. Assemblages of antiquated objects with sinister ornamental details alluded to the study and transfer of natural history specimens from colonial Australia to the centre of empire. Animal bones and skulls were incorporated into furniture and light fittings to create an uncanny conjunction between nature, culture and science. Referring to poet and critic Susan Stewart's understanding of the antiquarian in her renowned book On Longing, I sought both to distance and appropriate this past to make my own colonial settler heritage something strange and other. Stewart explains that, in order to entertain an antiquarian sensibility:

a rupture in historical consciousness must have occurred, creating a sense that one can make one's own culture other-distant and discontinuous. Time must be seen as concomitant with a loss of understanding, a loss which can be relieved through the reawakening of objects and, thereby, a reawakening of narrative. (1993: 142)

Opposite the entrance to Dark Manners was an occasional table on which sat a set of kangaroo-skull boat craft. On either side was a silhouette of Joseph Banks and King George III. This work, titled Bushcraft, set the scene for Dark Manners by presenting the backstory of Banks and Hunter and the collecting of their first kangaroo skulls in the interests of science and eventual colonial expansion. 


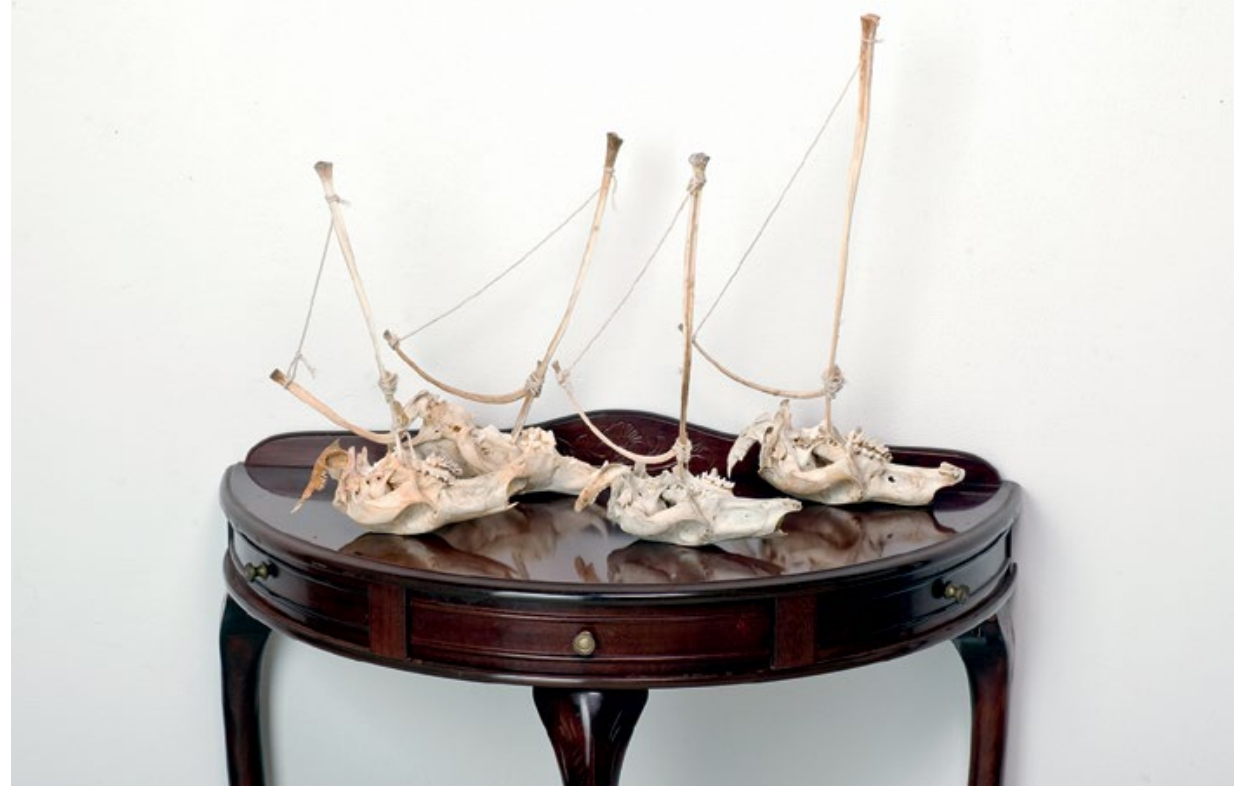

Figure 3. Sue Kneebone, Bushcraft, 2013, kangaroo skulls, string and bones on occasional table, $60 \times 50 \times 40 \mathrm{~cm}$

Photo: Michal Kluvanek

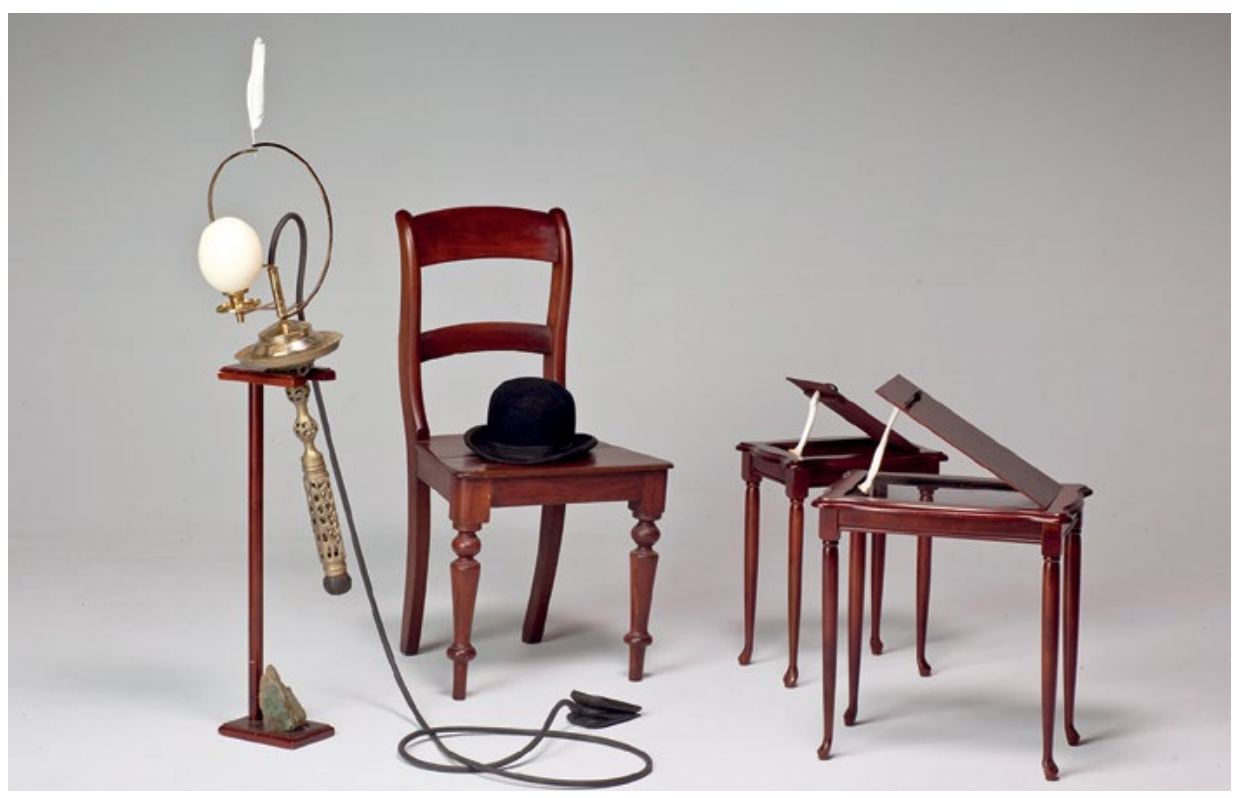

Figure 4. Dark Manners installation detail; left: Sue Kneebone, Devolution, 2013, furniture and mixed media, variable dimensions; right: Sue Kneebone, Overtones, 2013, tables, flywire, bones

Photo: Michal Kluvanek 
In his study of the bourgeois system of objects, sociologist and philosopher Jean Baudrillard critiques the class-related phenomenon of refinement, describing, for example, the bourgeois interior as dependent on the discretion of 'tints and nuances' (cited in Stewart 1993: 29). Susan Stewart draws on Baudrillard's argument that muted tones, such as mahogany, teak and tinted stains and veneers, mark 'a moral refusal of colour in the bourgeois world'. Refinement, Stewart says, 'has to do with not only the articulation of detail but also the articulation of difference, an articulation which has increasingly served the interests of class' (1993: 29).

In Dark Manners, individual assemblages bring together a peculiar mix of polished veneers, brass and glass with animal remains such as bones, skulls, eggs, feathers and fur. In her essay on the exhibition, Jane Goodall described how the 'fur, feather and bone are released from containment, and set in relationship to highly crafted items of mahogany and brass. The works are combinations of objects belonging to incommensurate orders of reality, marked out in visual terms as the rough and the smooth, the jagged and the straight, the frayed edge and the curvilinear outline' (2013).

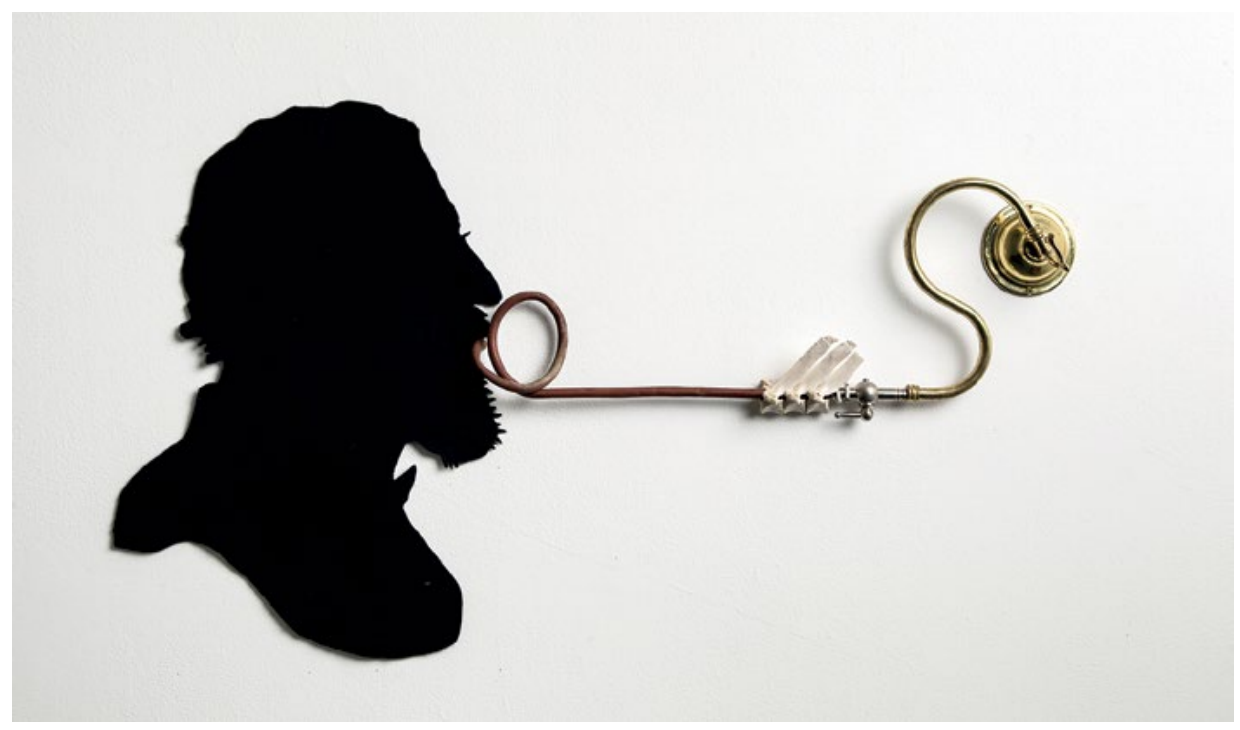

Figure 5. Sue Kneebone, Harmful benefits, 2013, felt, rubber, brass, bone, $80 \times 30 \mathrm{~cm}$ Photo: James Field

In the work Harmful benefits, the felt silhouette portrait of curator and conservator Sir William Henry Flower is juxtaposed with a nonsensical apparatus assembled from rubber, bones and brass. The work's title hints at the contradictory practices of museum curators such as Flower, who maintained a respectable standing in society on one hand while, on the other, engaging in a dark trade in human remains. Goodall notes that in taking away a sense of the familiar order comes disconcertment: 
To the colonial eye, what made sense of this incongruity was a hierarchical schema that supported processes of aesthetic and cognitive evaluation. When all that sense-making apparatus is stripped away, leaving the objects no context but each other, they acquire a strange equilibrium through physical interdependencies. (2013)

The middle room of Dark Manners presented an anachronistic style of laboratory, where bellows, tubes and spirit bottles brought to mind a Gothic world continuing to push the boundaries between life and death. In the tableau The nervous art of science (2013), projections of centuries-old life masks and death masks rise cyclically above the laboratory table. The images included the demonic face mask of John Hunter, which resides in the Edinburgh Anatomy Museum.

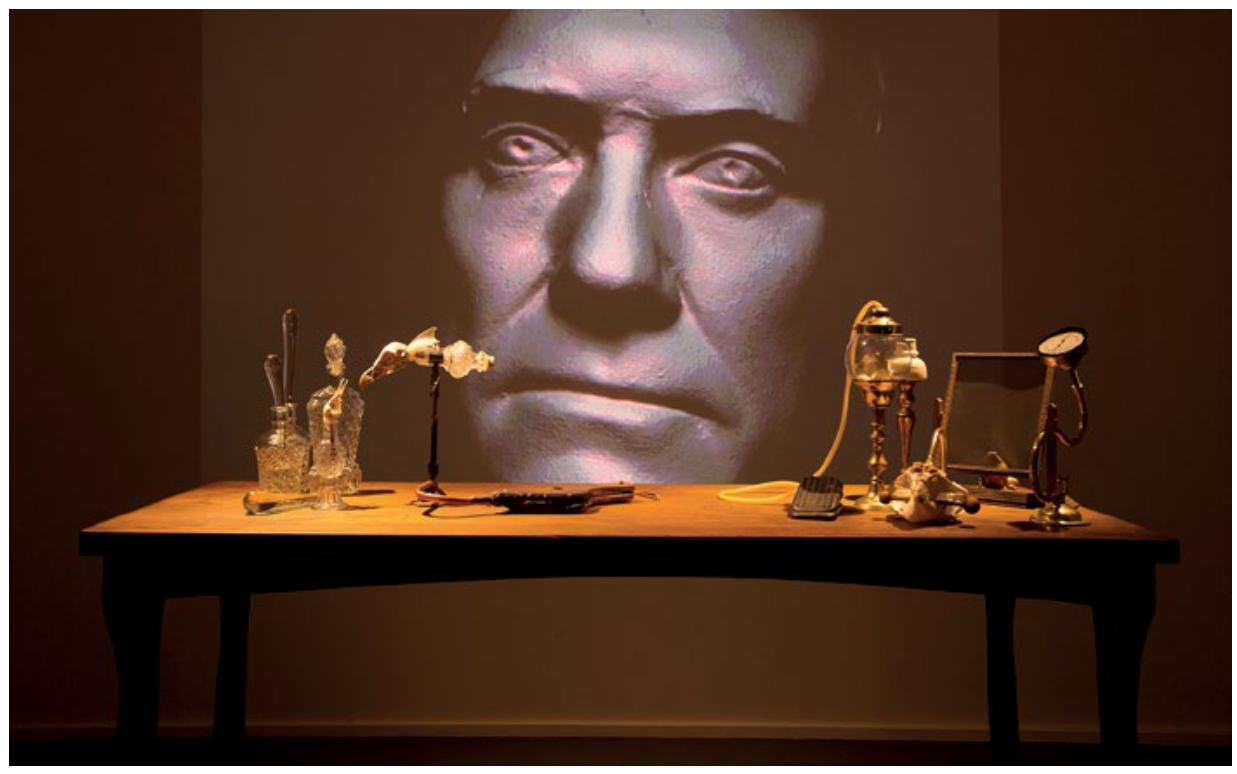

Figure 6. Sue Kneebone, The nervous art of science, 2013, glass, wood, brass, video projection, bones, found objects, approx. $200 \times 100 \times 200 \mathrm{~cm}$

Photo: James Field

In the back room, a reliquary of camel bones and prayer stools suggested the clash of ideas between science and religion that emerged from the time of enlightenment, when science experiments included attempts to measure the soul by weight in the belief that the separation of flesh and bone reflected the separation of body and spirit. Like Hunter's dissecting room, this final exhibition gallery was hidden at the rear. Its extensive and explicit assembly of skeletal remains allowed visitors to Dark Manners to gain a visceral sense of the duplicity of scientific collecting practices, distanced by remoteness and obscured by respectability. 


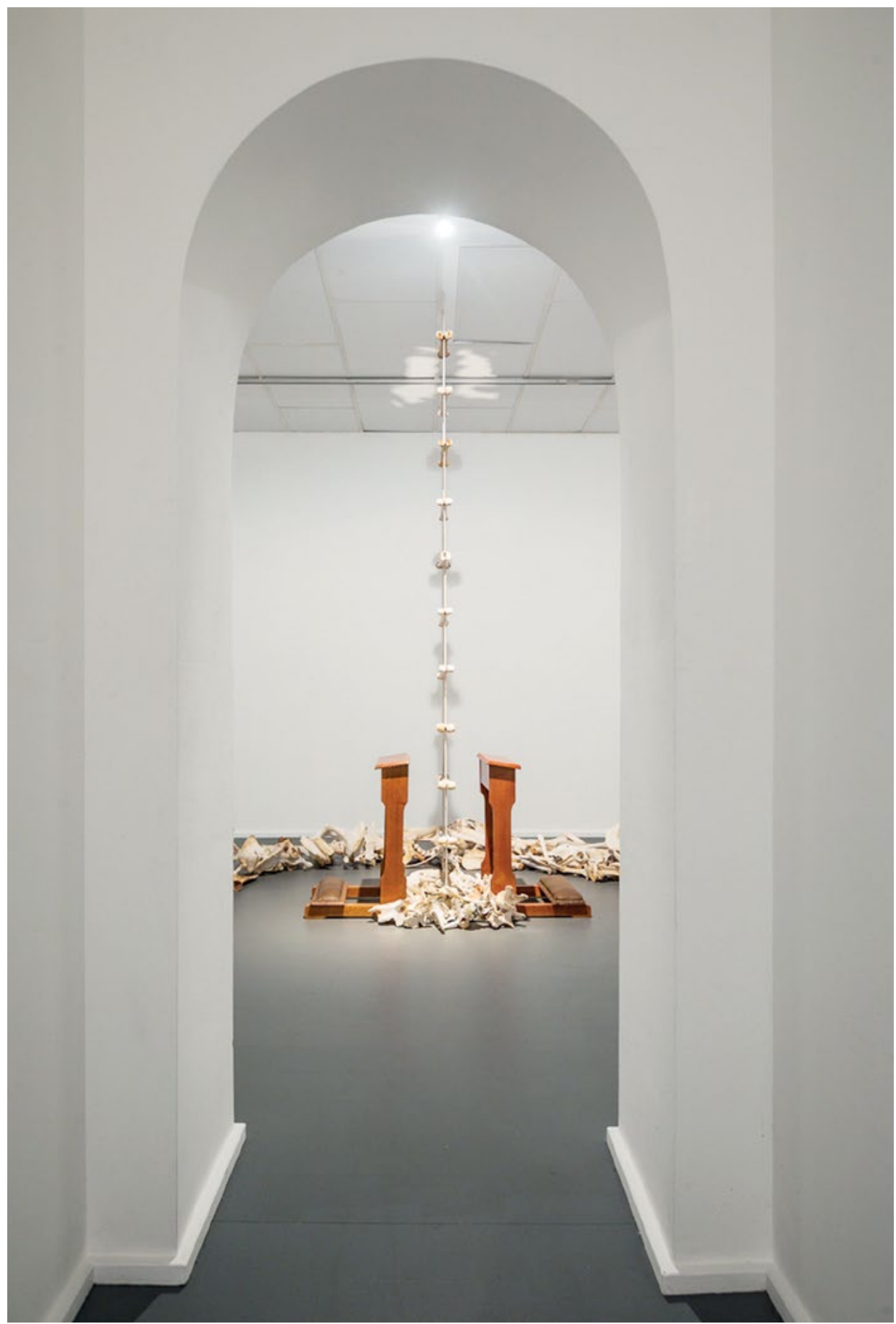

Figure 7. Sue Kneebone, Quarry of souls, 2013, camel bones, prayer stools, rope, approx. $300 \times 300 \times 200 \mathrm{~cm}$

Photo: James Field 
Throughout Western art history, bones have symbolised death, destruction and mortality, yet they are the most enduring of corporeal remains after death and a material link to loss, absence and irredeemable change. Bones are physical reminders of what has gone before and is lost forever - they link the past with the present. In the context of museum collections since the nineteenth century, however, human remains have been separated from their humanity.

The museum experience in Victorian society distanced viewers of such specimens from the uncomfortable reality of their origins (Alberti 2011: 184). Museums privileged sight at the expense of other senses that may evoke disgust, such as smell, touch and sound-indeed, the concept of disgust played a significant role in the civilising process in Victorian society by enculturating norms of cleanliness, reserve and restraint. Once on display, bones become passive participants.

Mike Pickering points out that today's curators are fortunate because the 'experiential circumstances of the individuals' lives and deaths have become "lost in time"' (2010: 14). He raises the disturbing reality that collections of human remains often comprise individuals who were not far removed in time from the collector. Once they enter the glass vitrines of the museum, however, history protects viewers from the trauma:

The passing of time filters out the horrors, emotions, and the social impacts until ultimately we are left with the institutional and professional objectification of life and death. Everything is neat, clean, tidy, and boxed. History still works to protect us from the full trauma of events that occurred at the time of the trans-substantiation of individuals into a museum's 'sacred objects'. (2010: 81)

In nineteenth-century museums, human bones became passive participants in ethnographic collections, where the identity of the individual is denied through the systemic process of collecting. Human remains in museums are ethnographic souvenirs of the colonial project. Susan Stewart writes on how, as souvenirs of death, bones become potent anti-souvenirs: 'If the function of the souvenir proper is to create a continuous and personal narrative of the past, the function of such souvenirs of death is to disrupt and disclaim that continuity' (Stewart: 140).

\section{Conclusion}

Like the house of Dr Jekyll, Dark Manners presented the uneasy duality of comfortable respectability and dark menace that united certain men of science in the British imperial metropole and the Australian colonies, such as John Hunter and William Ramsay Smith. From its parlour room frontage, through its curtained laboratory of contorted scientific experimentation to its rear 
charnel house of bones ascending to heaven, the exhibition layout sought to lure visitors deeper into the Jekyll and Hyde space that venerable physician anatomists occupied in the nineteenth century. A pervasively Gothic sensibility accentuated these dark connections. Period-style furniture and domestic objects, repurposed or reassembled to incorporate bone, fur or other animal remains, strove to unsettle the appearance of domestic comfort by materialising the unfamiliar in the familiar, the concealed in the conventional, the unwelcome in what should be welcoming.

This was the unheimlich made manifest. In what should be a relaxing interior, settler society's ambitions of comfort and respectability were unsettled by the surfacing of uncomfortable reminders.

Implicit in Dark Manners was an interrogation of issues that strain against national identity. The collection practices of anatomists contained the silent premise that the collected remains came from the 'other'-be they the poor in early nineteenth-century Britain, the criminal, the medically unusual or Indigenous people of colonial Australia. Made remote, human remains were treated similarly to animal remains. Well into the latter part of the twentieth century, collections held by lauded individuals or state institutions embraced and reinforced white settler society's notions of 'ourselves' by their objectification of what was outside 'ourselves'. Such notions, reinforced with the imprimatur of science, were critical to the formation of the identity of the nation that white settler society became-and in many ways they remain so. It is a haunting past that lingers still.

Sue Kneebone completed her Masters in fine art at the Victorian College of the Arts in 2000 and her PhD in visual arts at the University of South Australia in 2010. She has exhibited nationally and her works have been collected by the Art Gallery of South Australia and private collectors. Sue has been a recipient of various grants and awards including an Australia Council Grant for new work.

\section{References}

Alberti, S.J., 2011, Morbid Curiosities: Medical Museums in Nineteenth Century Britain, Oxford University Press.

Baynton, B., 2001 (1902), Bush Studies, HarperCollins.

Foster, R., Nettlebeck, A. and Hosking, R., 2001, Fatal Collisions, Adelaide: Wakefield Press.

Gelder K. and Weaver, R. (eds), 2001, The Anthology of Colonial Australian Fiction, Melbourne University Press. 
Goodall, J., 2013, 'Strangers in the land', suekneeboneart.files.wordpress. com/2013/07/strangersinthelandjanegoodall.pdf.

Halberstam, J., 1995, 'Skin shows. Gothic horror and the technology of monsters', in G. Williams (ed.), The Gothic, Documents of Contemporary Art, London: Whitechapel.

Katz, J.D., 2008, “'Committing the perfect crime”: Sexuality, assemblage, and the postmodern turn in American art', Art Journal, vol. 67, no. 1, pp. 38-53.

Kneebone, S., 2010, 'Naturally disturbed: Critical inquiry into pastoralist memory and environmental history as realised through visual art', PhD thesis, South Australian School of Art, University of South Australia.

MacDonald, H., 2010, Possessing the Dead, Melbourne University Press.

Moore, M., 2005, The Knife Man, London: Bantam Books.

Farr, I. (ed.), 2012, Memory, Documents of Contemporary Art, London: Whitechapel Gallery.

Pickering, M., 2010, 'Where are the stories?', The Public Historian, vol. 32, no. 1, pp. 79-95.

Scobie, C., 2009, 'Return of the bones', Meanjin, vol. 4, no. 8, viewed 21 May 2014, meanjin.com.au/editions/volume-68-number-4-2009/article/ the-return-of-the-bones/.

Stevenson, R.L., 1886, The Strange Case of Dr. Jekyll and Mr. Hyde, Longmans, Green \& Co.

Stewart, S., 1993, On Longing: Narratives of the Miniature, the Gigantic, the Souvenir, the Collection, London: Duke University Press.

The Royal College of Surgeons of England, Archive of Museum Correspondence, Museum Letterbook Series 2, 1857-1906, viewed 30 March 2013, www.rcseng.ac.uk/museums/hunterian/documents/MLB2name.pdf.

Turcotte, G., 2005, 'Vampiric decolonization: Fanon, “Terrorism” and Mudrooroo's Vampire Trilogy', Faculty of Arts - Papers, viewed 25 June 2010, works. bepress.com/gturcotte/4.

--, 1998, Australian Gothic, Faculty of Arts - Papers, viewed 19 June 2010, works.bepress.com/gturcotte/11.

Turnbull, P., 'Science and the morphology of the Aboriginal Australian brain', School of HPRC Seminar paper, University of Queensland, viewed 20 March 2013, www.paulturnbull.org/57. 
—, 2012, 'A judicious collector: Edward Charles Stirling and the procurement of Aboriginal bodily remains in South Australia, c. 1880-1912', in S. Ferber and S. Wilde (eds), The Body Divided: Human Beings and Human 'Material' in Modern Medical History, Ashgate.

Warner, M., 2002, Fantastic Metamorphoses, Other Worlds, Oxford University Press. 
This text is taken from Craft + Design Enquiry, Issue 7, 2015, edited by Kay Lawrence, published 2015 by ANU Press, The Australian National University, Canberra, Australia. 